\title{
Web Based Information System of Carbon Monoxide Pollution
}

\author{
Wibowo Harry Sugiharto ${ }^{1, *}$, Aditya Akbar Riadi ${ }^{1}$, and Muhammad Imam Ghozali ${ }^{1}$ \\ 1 Department of Informatics Engineering, Faculty of Engineering, Universitas Muria Kudus, Kudus - Indonesia
}

\begin{abstract}
In Indonesia, carbon monoxide is one of which type of gas used as a parameter in the air pollution. Unfortunately, reporting and monitoring air pollution in Indonesia is regulated in government rules and reported once a day. The value of carbon monoxide concentration always change but the published information is out of date. Without real-time information, people cannot avoid the danger of monoxide pollution toxicity effect. This paper purpose the solution by publishes the real-time information from the carbon monoxide sensor data acquisition. This Research uses the rule-based method to calculate carbon monoxide pollution from data acquisition. Results of experiments show that information generated by the system in accordance with the manual calculation results of carbon monoxide pollution. This research contributed to providing information on real-time carbon monoxide measurement to the public, so the danger of carbon monoxide poisoning can be avoided.
\end{abstract}

Keywords: Rule-Based; Carbon Monoxide; Air Pollution; Real-Time Measurement System ;

\section{Introduction}

Rule-based methods are very easy to implement in a system so that the system can behave intelligently [1], one of its applications to monitor air pollution. because air is one of the determinants of environmental quality that today has become a serious issue. Some of the gases officials used to determinate Air Quality Index in Indonesia are sulfur dioxide (SO2), carbon monoxide (CO), Nitrogen Dioxide (NO2), Ozone (O3), and Particulate (PM10) [2].

Carbon monoxide $(\mathrm{CO})$ is an indicator of air quality. $\mathrm{CO}$ is colorless and odorless but at high concentrations, $\mathrm{CO}$ becomes a highly toxic gas[3], Carbon monoxide poisoning is common, resulting in more than 50,000 emergency department visits per year in the United States [4]. Carbon monoxide has an affinity for hemoglobin 200-250 times that of oxygen, and the symptoms and signs that follow inhalation of carbon monoxide have been supposed to result from tissue hypoxia. Carbon monoxide combines with hemoglobin to form carboxyhemoglobin, reducing the total capacity of the blood to carry oxygen and shifting the oxygen dissociation curve to the left[5]. The symptoms of carbon monoxide poisoning are nonspecific. Mild exposures result in a headache, myalgia, dizziness, or neuropsychological impairment. Severe exposures to carbon monoxide result in confusion, loss of consciousness, or death [6].

Air pollution resulting from fossil fuel combustion has become an important problem, especially for countries with an increasing energy demand and inherent fuel consumption[3]. Real-time Monitoring of Carbon monoxide concentration is important because it is particularly dangerous as it cannot be detected by man's natural sense organs[7]. In Indonesia air quality index reporting to the public is not done in real-time, AQI reporting to the public is only done once a day and is valid 24 hours from 15.00 WIB [2], The real-time data acquisitions has become a major issue [8][9][10][11], especially in air pollution monitoring [12][13] The value of carbon monoxide concentration always change but the published information is out of date. Without real-time information, people cannot avoid the danger of monoxide pollution toxicity effect.

Computer network-based automation can improve work effectiveness in measurement in processing. Computer-based systems are more precise and faster in execution so it is suitable for measurements that require high response speeds [14]. The real-time information can be used as a reference to handling and reducing carbon emission for developing low carbon society.

\section{Related Work}

Over the past few years, many research of air pollution has mainly focused on forecasting the concentrations of air quality $[15][16][17][18][19]$ and air quality measurement [20][21][22][23][24].

The forecasting of air quality became popular, many methods have been purposed for forecasting air quality such as hidden Markov model[15], first-order and one-variable grey model [16], developed support vector machine [17], fuzzy time series model [18][19][25], Solar Radiation[26], and Fuzzy-AHP[27].

Compared with forecasting, determination of air pollution has recently become an important issue due to

* Corresponding author: maryono@pwk.undip.ac.id 
its significance, and several new methodologies have been developed for the determination of air quality, such as Fuzzy-AHP[27], artificial neural networks[28], and real-time measurement[29].

Based on the literature on the determination of air quality mentioned above, real-time measurement became an important issue since air pollution parameters difficult detected by a human body. Real-time measurement of carbon monoxide sensor adopts to combine with the rule-based method. The rule-based method is a very easy method to create system act intelegently[30]. Combination of rule-based served the information of real-time carbon monoxide measurement to the public.

\section{Methodology}

\subsection{Real-time Data Acquisition}

The purpose of real-time data acquisition in this paper using carbon monoxide sensors to capture the carbon monoxide concentration. The sensors installed on the node station and send data acquisition to send into web service, after the process of determination of air quality, the result will publish into public as a real-time information of carbon monoxide pollution.

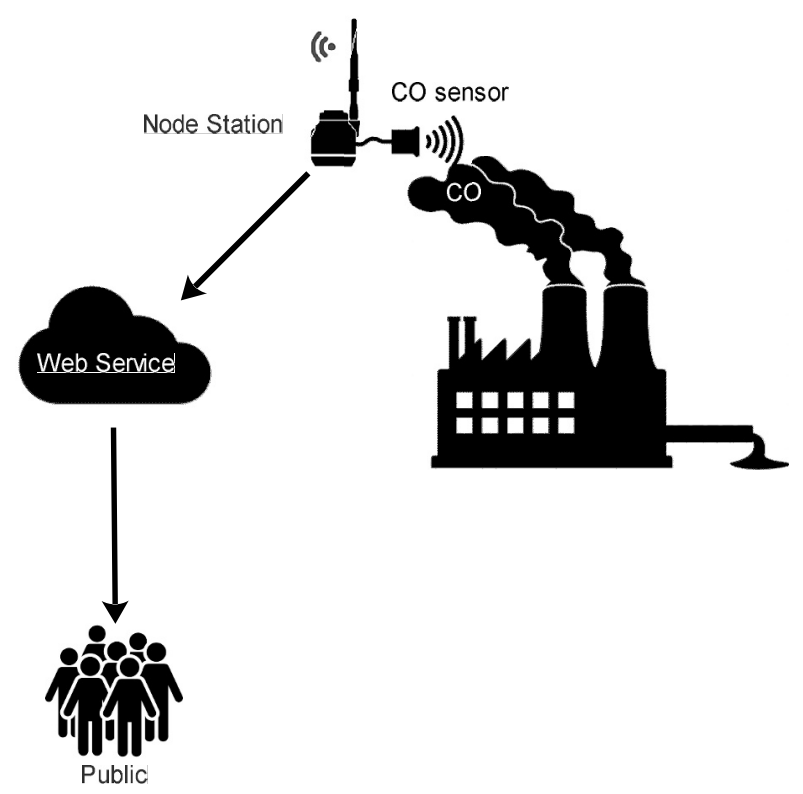

Fig.1 Real time carbon monoxide aquisition

\subsection{Indonesian Air Quality Index}

In Indonesia the Air Quality Index Calculation Method is based on government rules, this Air Quality Index is adapted to determine the carbon monoxide pollution. About Technical Guidance of Calculation and Reporting and Information of Indonesian Air Quality Index as follows :

$$
I=\frac{I_{A}-I_{B}}{X_{A}-X_{B}}\left(X_{X}-X_{B}\right)+I_{B}
$$

With I is the calculated AQI, IA is the upper limit AQI, IB is the lower limit AQI, XA is the upper ambient limit, $\mathrm{XB}$ is the lower ambient limit, and $\mathrm{XX}$ is the real ambient content of the measurement result. The values of IA, and XB are based on the AQI boundary table as shown in Table 1. Index Number and Category of Indonesian Air Quality Index based on government rules are showed in Table 2.

Table 1. Air Quality Index Limit

\begin{tabular}{|c|c|c|c|c|c|}
\hline $\begin{array}{c}\text { Air Quality } \\
\text { Index }\end{array}$ & $\begin{array}{c}\mathbf{2 4} \\
\text { Hour } \\
\mathbf{P M 1 0} \\
\mathbf{u g} / \mathbf{m} 3\end{array}$ & $\begin{array}{c}\mathbf{8} \\
\text { Hour } \\
\mathbf{S O 2} \\
\mathbf{u g} / \mathbf{m 3}\end{array}$ & $\begin{array}{c}\mathbf{8} \\
\text { Hour } \\
\mathbf{C O} \\
\mathbf{u g} / \mathbf{m 3}\end{array}$ & $\begin{array}{c}\mathbf{1} \\
\mathbf{H o u r} \\
\mathbf{O 3} \\
\mathbf{u g} / \mathbf{m 3}\end{array}$ & $\begin{array}{c}\mathbf{1} \\
\text { Hour } \\
\mathbf{N O 2} \\
\mathbf{u g} / \mathbf{m 3}\end{array}$ \\
\hline 50 & 50 & 80 & 5 & 120 & \\
\hline 100 & 150 & 365 & 10 & 253 & \\
\hline 200 & 350 & 800 & 17 & 400 & 1130 \\
\hline 300 & 420 & 1600 & 34 & 800 & 2260 \\
\hline 400 & 500 & 2100 & 46 & 1000 & 3000 \\
\hline 500 & 600 & 2620 & 57.5 & 1200 & 3750 \\
\hline
\end{tabular}

Table 2. Index Number And Category Of Indonesian Air Quality Index

\begin{tabular}{|c|c|}
\hline Category & Range \\
\hline Good & $0-50$ \\
\hline Medium & $51-100$ \\
\hline Unhealthy & $101-199$ \\
\hline Very Unhealthy & $200-299$ \\
\hline Dangerous & Over 299 \\
\hline
\end{tabular}

\subsection{Modeling of Indonesian Air Quality Index using Rule-Based Method}

AQI formulation modeling using the rule-based method, in the determination of IA, IB, XA, and XB based on AQI boundary table as in Table 1.

Step 1: Define XX

Step 2: Determine the IA

IA determine with the rule :

If XX less than 6, then IA is 50

If $\mathrm{XX}$ more than 5 , and below 11 , then IA is 100

If $\mathrm{XX}$ more than 10 , and below 18 , then IA is 200

If $\mathrm{XX}$ more than 17 , and below 35 , then IA is 300

If $\mathrm{XX}$ more than 34 , and below 47 , then IA is 400

If $\mathrm{XX}$ more than 46 , then IA is 500

Step 3: Determining the IB

IB determine with the rule :

If $\mathrm{XX}$ less than 6, then IB is 0

If XX more than 5, and below 11, then IB is 50

If XX more than 10, and below 18, then IB is 100

If $X X$ more than 17, and below 35, then IB is 200

If XX more than 34, and below 47, then IB is 300

If $\mathrm{XX}$ more than 46 , then IB is 400

Step 4: Define XA

$\mathrm{XA}$ determine with the rule : 
If $\mathrm{XX}$ less than 6, then $\mathrm{XA}$ is 5

If $\mathrm{XX}$ more than 5 , and below 11 , then $\mathrm{XA}$ is 10

If $\mathrm{XX}$ more than 10 , and below 18 , then $\mathrm{XA}$ is 17

If $\mathrm{XX}$ more than 17, and below 35, then XA is 34

If $\mathrm{XX}$ more than 34 , and below 47 , then $\mathrm{XA}$ is 46

If XX more than 46 , then XA is 57.5

Step 5: Define XB

$\mathrm{XB}$ determine with the rule :

If $\mathrm{XX}$ less than 6 , then $\mathrm{XB}$ is 0

If $\mathrm{XX}$ more than 5 , and below 11 , then $\mathrm{XB}$ is 5

If $\mathrm{XX}$ more than 10 , and below 18 , then $\mathrm{XB}$ is 10

If $\mathrm{XX}$ more than 17 , and below 35 , then $\mathrm{XB}$ is 17

If $\mathrm{XX}$ more than 34 , and below 47 , then $\mathrm{XB}$ is 34

If XX more than 46 , then XB is 46

Step 6: Calculate I, the calculation I is done using equation (1)

Step 7: Perform rounding of calculation result I

Step 8: Define the category and color of AQI according to Table 2

\section{Result and Discussion}

\subsection{Implementation}

Implementation of the Indonesian AQI Model is applied to web-based applications that display the location of the station, the graph of the acquisition value, and the pollution of carbon monoxide measurement table using the system. It is shown in fig. 2 .

\subsection{Verify the results of implementation Indonesian Air Quality Index monitoring system}

Verification is done by testing the conformity of the calculation result with the system and the ambient air quality data of Pontianak city on August 26, 2014. The result of the match test is shown in Table 3

Table 3. Verify The Results Of Implementation Indonesian Air Quality Index Monitoring System

\begin{tabular}{|c|c|c|c|c|c|c|c|}
\hline \multirow{2}{*}{ No } & \multirow{2}{*}{$\begin{array}{c}\text { Acquisiti } \\
\text { on } \\
\text { Time }\end{array}$} & \multirow{2}{*}{$\begin{array}{c}\text { CO } \\
\text { (ug/ } \\
\text { m3) }\end{array}$} & \multicolumn{2}{|c|}{$\begin{array}{c}\text { AQI Pontianak } \\
\text { City August }\end{array}$} & \multicolumn{2}{|c|}{$\begin{array}{c}\text { AQI Calculation } \\
\text { Using System }\end{array}$} & \multirow{2}{*}{ Match } \\
\cline { 5 - 7 } & AQI & Cat & AQI & Cat & \\
\hline 1 & $00: 00: 00$ & 3.87 & 39 & GOOD & 39 & GOOD & Yes \\
\hline 2 & $00: 30: 00$ & 3.98 & 40 & GOOD & 40 & GOOD & Yes \\
\hline 3 & $01: 00: 00$ & 4.05 & 41 & GOOD & 41 & GOOD & Yes \\
\hline 4 & $01: 30: 00$ & 4.12 & 41 & GOOD & 41 & GOOD & Yes \\
\hline 5 & $02: 00: 00$ & 3.88 & 39 & GOOD & 39 & GOOD & Yes \\
\hline 6 & $02: 30: 00$ & 3.69 & 37 & GOOD & 37 & GOOD & Yes \\
\hline 7 & $03: 00: 00$ & 3.41 & 34 & GOOD & 34 & GOOD & Yes \\
\hline 8 & $03: 30: 00$ & 3.53 & 35 & GOOD & 35 & GOOD & Yes \\
\hline 9 & $04: 00: 00$ & 2.42 & 24 & GOOD & 24 & GOOD & Yes \\
\hline 10 & $04: 30: 00$ & 2.41 & 24 & GOOD & 24 & GOOD & Yes \\
\hline 11 & $05: 00: 00$ & 2.45 & 25 & GOOD & 25 & GOOD & Yes \\
\hline 12 & $05: 30: 00$ & 2.22 & 22 & GOOD & 22 & GOOD & Yes \\
\hline 13 & $06: 00: 00$ & 1.35 & 14 & GOOD & 14 & GOOD & Yes \\
\hline 14 & $06: 30: 00$ & 1.57 & 16 & GOOD & 16 & GOOD & Yes \\
\hline
\end{tabular}

\begin{tabular}{|c|c|c|c|c|c|c|c|}
\hline \multirow{2}{*}{ No } & \multirow{2}{*}{$\begin{array}{c}\text { Acquisiti } \\
\text { on } \\
\text { Time }\end{array}$} & \multirow{2}{*}{$\begin{array}{c}\text { CO } \\
\text { (ug/ } \\
\mathbf{m 3})\end{array}$} & \multicolumn{2}{|c|}{$\begin{array}{c}\text { AQI Pontianak } \\
\text { City August } \\
\mathbf{2 6 , 2 0 1 4}\end{array}$} & \multicolumn{2}{|c|}{$\begin{array}{c}\text { AQI Calculation } \\
\text { Using System }\end{array}$} & \multirow{2}{*}{ Match } \\
\cline { 5 - 7 } & & AQI & Cat & AQI & Cat & \\
\hline 15 & $07: 00: 00$ & 1.46 & 15 & GOOD & 15 & GOOD & Yes \\
\hline$\ldots$ & $\ldots$ & $\ldots$ & $\ldots$ & $\ldots$ & $\ldots$ & $\ldots$ & $\ldots$ \\
\hline 43 & $21: 00: 00$ & 2.19 & 22 & GOOD & 22 & GOOD & Yes \\
\hline 44 & $21: 30: 00$ & 3.37 & 34 & GOOD & 34 & GOOD & Yes \\
\hline 45 & $22: 00: 00$ & 1.57 & 16 & GOOD & 16 & GOOD & Yes \\
\hline 46 & $22: 30: 00$ & 2.14 & 21 & GOOD & 21 & GOOD & Yes \\
\hline 47 & $23: 00: 00$ & 1.6 & 16 & GOOD & 16 & GOOD & Yes \\
\hline 48 & $23: 30: 00$ & 2.41 & 24 & GOOD & 24 & GOOD & Yes \\
\hline
\end{tabular}

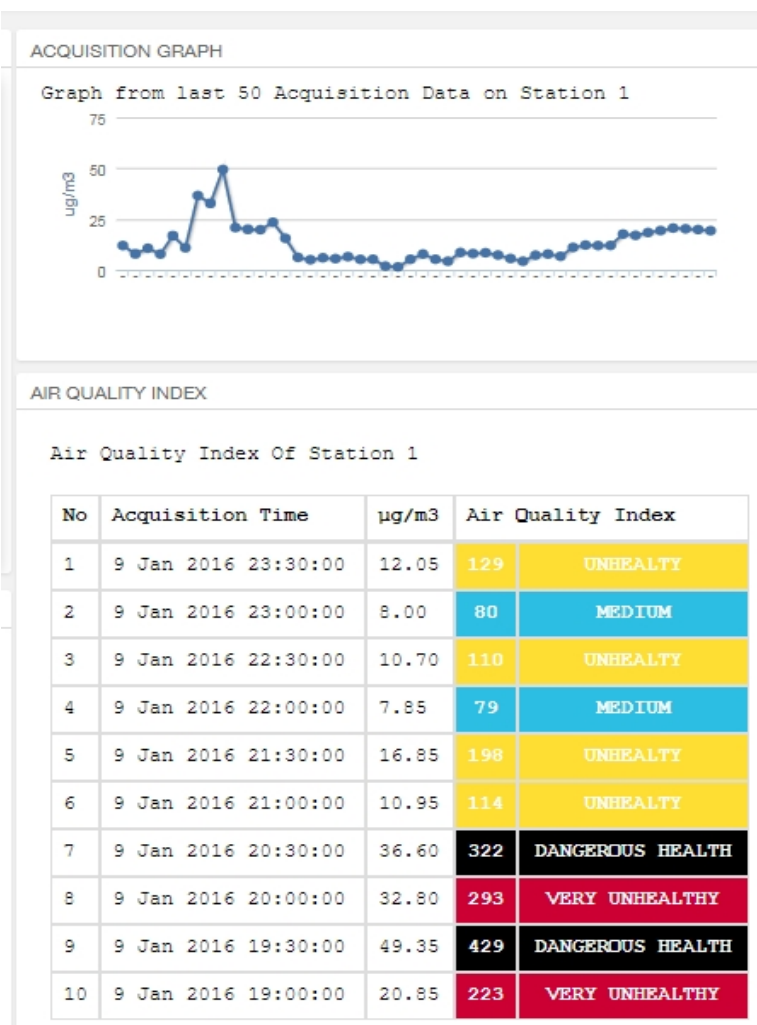

Fig. 2. Real-Time Measurement of Carbon Monoxide Pollution

\section{Conclusion}

From the results of this research can be concluded that clear rules have to be clear to building system using the rule-based system. This is proven by the calculation of air pollution from carbon monoxide gas using rule-based method has a $100 \%$ match rate compared to manual calculation.

The rule-based method can be adopted and combine with the real-time acquisition of carbon monoxide concentration to determinate the carbon monoxide pollution. The information about carbon monoxide pollution can be delivered as real-time public information to avoid the danger of carbon monoxide poisoning. The real-time information can be used as a reference to handling and reducing carbon emission for developing low carbon society 


\section{References}

1. Lukasiewicz, K., Teymourian, K., and Paschke , A., 2014, "A Rule-Based System for Monitoring of Microblogging Disease Report" The Semantic Web: ESWC 2014 Satellite Events - Lecture Notes in Computer Science 8798 401-406

2. Menteri Negara Lingkungan Hidup, 1997, "Keputusan Menteri Negara Lingkungan Hidup Nomor : KEP 45 / MENLH / 1997" Tentang Indeks Standar Pencemar Udara

3. Aldossary, M., Almadni, O., Kharoshah, M.,Alsaif, D., Alsowayigh, A., Alfaraidy, M.,2015, "Carbon monoxide toxicity in Dammam, KSA: Retrospective study" Egyptian Journal of Forensic Sciences (2015) 5, 36-38

4. Hampson NB, Weaver LK. "Carbon monoxide poisoning: a new incidence for an old disease" Undersea Hyperb Med 2007; 34:163-8.

5. Douglas, C. G., Haldane, and J. S., Haldane, J. B. S., 1912, "The Laws Of Combination of Haemoglobin With Carbon Monoxide And Oxygen" J Physiol 44 275-304.

6. Lindell K. Weaver, M.D., 2009, "Carbon Monoxide Poisoning" The New England journal of medicine $360 ; 12$

7. Prockop, Leon., 2009, "Carbon Monoxide" Clinical Neurotoxicology - CHAPTER 45, Pages 500-514

8. Otahalova, T., Slanina, Z., Vala, D., 2012, "Embedded Sensors System for Real-Time Biomedical Data Acquisition and Analysis" IFAC Proceedings Volumes Volume 45, Issue 7, 2012, Pages 261-264

9. Downeya, J., Bombinskib, S., Nejmanb, M., Jemielniakb, K., 2015, "Automatic multiple sensor data acquisition system in a real-time production environment" 9th CIRP Conference on Intelligent Computation in Manufacturing Engineering

10. Uhlemanna, T. H. J., Schocka, C., Lehmanna, C., Freibergera, S., Steinhilpera, R., 2017, "The Digital Twin: Demonstrating the potential of real time data acquisition in production systems" 7th Conference on Learning Factories, CLF 2017

11. Folkers, A., Mosch, F., Malina, T., Hofmann, U. G., 2003, "Realtime bioelectrical data acquisition and processing from 128 channels utilizing the wavelet-transformation" Neurocomputing 52-54 (2003) $247-254$

12. Kar , J., Vaughan, M. A., Liu, Z., Omar, A. H., Trepte, C. R., Tackett, J., Fairlie, T. D., Kowch, R., 2015, "Detection of pollution outflow from Mexico City using CALIPSO lidar measurements" Remote Sensing of Environment 169 (2015) 205-211

13. Rai, A. C., Kumar, P.,Pilla, F., Skouloudis, A. N., Sabatino, S. D., Ratti, C., Yasar, A., Rickerby, D., 2017, "End-user perspective of low-cost sensors for outdoor air pollution monitoring" Science of the Total Environment 607-608 (2017) 691-705

14. Suryono, S., Suseso, J. E., Mashuri, C., Sabila, A. D., Nugraha, J. A. M., Primasiwi, M. H., 2017, "RFID Sensor for Automated Prediction of Reorder Point (ROP) Values in a Vendor Management Inventory (VMI) System Using Fuzzy Time Series" Adavanced Science Letters Vol 23 2398-2400

15. Sun, W., Zhang, H., Palazoglu, A., Singh, A., Zhang, W., Liu, S., 2013, "Prediction of 24hour-average PM2.5 concentrations using a hidden Markov model with different mission distributions in Northern California" Sci. Total Environ. 443

16. Pai, T.Y., Hanaki, K., Chiou, R.J., 2013, "Forecasting hourly roadside particulate matter in Taipei county of Taiwan based on first-order and one-variable grey model" Clean e Soil Air Water 41, 737-742.

17. Moazami, A., Noori, R., Amiri, B. J., Jabbarian, B., Yeganeh, B., Partani, S., Safavi, S., 2015, "Reliable prediction of carbon monoxide using developed support vector machine" Atmospheric Pollution Research Volume 7, Issue 3, May 2016, Pages 412-418

18. Aripin, A., Suryono, S., Bayu, S., 2016, "Web based prediction of pollutant PM10 concentration using Ruey Chyn Tsaur fuzzy time series model" AIP Conference Proceedings Volume 1746, Issue 1

19. Dincer, N. G., Akkus, Ö., 2018, "A new fuzzy time series model based on robust clustering for forecasting ofair pollution" Ecological Informatics 43 (2018) 157-164

20. Suryono, S., Surarso, B., Saputra. R., Bardadi. A., 2017, "A Web-Based Wireless Sensor System to Measure Carbon Monoxide Concentration" 2017 4th International 
Conference on Electrical Engineering, Computer Science and Informatics (EECSI)

21. Nastro, V., Carni, D.L., Vitale, A., Lamonaca, F., Vasile, M.,2018, "Passive and active methods for Radon pollution measurements in historical heritage buildings" Measurement Volume 114, January 2018, Pages 526-533

22. Sammarcoa, M., Tse, R., Paua, G., Marfia, G.,2017, "Using geosocial search for urban air pollution monitoring" Pervasive and Mobile Computing Volume 35 - 2017 Pages 15-3

23. Noblesa, C. J., Schistermana, E. F., Haa. S., Kima, K., Mumforda, S. L., Louisc, G. M. B., Chend, Z., Liud, D., Shermane, S., Mendolaa, P., 2018, "Ambient air pollution and semen quality" Environmental Research 163 (2018) 228-236

24. Mukerjee, S., Smith, L., Brantley, H., Stallings. C., Neas, L., Kimbrough, S., Williams, R.,2015, "Comparison of modeled traffic exposure zones using on-road air pollution measurements" Atmospheric Pollution Research 6 (2015) 82-87

25. Suryono, S., Surarso, B., Bardadi, A., 2017, "Wireless Sensor System for Prediction of Carbon Monoxide Concentration using Fuzzy Time Series" Proc. EECSI 2017 567-572
26. Espino, D. J., Lopez, E. C., Hernandez, J. R., Muñoz, F. B., 2018, "Air quality modelling in Catalonia from a combination of solar radiation, surface reflectance and elevation"Science of the Total Environment 624 (2018) 189-200

27. Wang, J., Zhang, X., Guo, Z., Lu, H., 2017, Developing an early-warning system for air quality prediction and assessment of cities in China" Expert Systems with Applications Volume 84, 30 October 2017, Pages 102-116

28. Mishra, D., Goyal, P., 2016, "Neuro-fuzzy approach to forecast NO2 pollutants addressed to air quality dispersion model over Delhi", India. Aerosol Air Qual.Res. 16, 166-174.

29. Steffens, J., Kimbrough, S., Baldauf, R., Isakov, V., Brown, R., Powell, A., Deshmukh, P., 2017, "Near-port air quality assessment utilizing a mobile measurement approach" Atmospheric Pollution Research Volume 8, Issue 6, November 2017, Pages 1023-1030

30. Buchanan, B. G., 1983, "Principles of RuleBased Expert Systems" Department of Computer Science - Stanford University Stanford. California 